\title{
Accounting Records Using the Android Application to Evaluate Changes in Earnings
}

\author{
Avincennia Vindy Fitriana, Indra Wijaya, Chita Oktapriana \\ Faculty of Business, Accounting Program, Bina Insani University \\ Email: avincennia@binainsani.ac.id
}

\section{A R T I C L E IN F O}

Date of entry:

05 July 2020

Revision Date:

20 August 2020

Date Received:

10 September 2020

\begin{abstract}
A B S T R A C T
The purpose of this research is to test the difference in the logging of profit conducted by Micro, Small, and Medium Enterprises (MSME) with the recording in accordance with accounting standards and to test the feasibility of Akuntansi UKM application in the implementation in MSME business. The respondents of this research are the MSME in Bekasi City under the Dinas Koperasi dan UKM. There were 40 respondents in this study. This research is a case study research and uses quantitative descriptive methods. Data analysis Using test paired t-test and application feasibility test using PIECES. The results of this research are there is a difference between the average profit that has been recorded by the respondents with the profit recorded in accordance with the financial accounting standards, and the Akuntansi UKM application has fulfilled the eligibility criteria so that it can be applied in business actors, especially MSME.
\end{abstract}

Keywords: Micro, Small, Medium Enterprises, PIECES, Accounting Application

Cite this as: Fitrinana, A. V., Wijaya, I., Oktapriana, C. (2020). Accounting Records Using the Android Application to Evaluate Changes in Earnings. Wiga : Jurnal Penelitian Ilmu Ekonomi, 1O(2), 132-147. https://doi.org/10.30741/wiga.v10i2.556

\section{INTRODUCTION}

In the Era of Industrial Revolution 4.0, many businesses were required to be more advanced in conducting their business, including accounting. One type of business in Indonesia that are widely involved by the community is Micro, Small, and Medium Enterprises (MSME). The business sectors that include in MSME play an important role in the Indonesian economy, evidenced by the increase of Gross Domestic Product (GDP) year by year (Savitri and Saifudin, 2018). In addition to increasing GDP, MSME can also improve Gross Regional Domestic Product (GRDP), such as the city of Bekasi annually, in the increase of GRDP. The average increase in GRDP in 2014-2018 is 5\% (BPS, 2019). The number of MSME in Bekasi throughout the year 2018 has increased. The MSME Data of the Bekasi city to 2018 reached 2,866 MSME, and this increased from the number of MSME in 2017, namely 2,667 MSME (Cendana News, 2018). In the year 2019, Bekasi City focuses on MSME empowerment ranging from packaging, marketing, and promotion. The important thing about MSME empowerment is not only on these three aspects but in terms of 
accounting recording is also important for MSME in drafting accurate financial statements so that they can be used as the basis for decision making.

One of the challenges faced by MSME is the management of funds (Savitri and Saifudin, 2018). The method of fund management that can be applied by MSME is to implement accounting well in order to obtain financial information that is important in running its business (Kurniawati, Nugroho, \& Arifin, 2012). According to Pinasti (2007), Accounting information can be an accurate basis for small businesses in market development decision making, pricing, etc. Accounting records must comply with the applicable financial accounting standards. Accounting standards have an accounting treatment ranging from the recognition, measurement, presentation, or disclosure that is the basis of the preparation of financial statements (Andrianto, Nuraini, \& Maharani, 2017; Kurniawati, Nugroho, \& Arifin, 2012). The application of accounting in the presentation of financial statements is difficult to apply for MSME because of the limitation of Science on accounting, the complexity of the accounting process, and the assumption that the financial statements are not important for MSME (Savitri and Saifudin, 2018).

Indonesian Institute of Accountants publishes Financial accounting standards for MSME, i.e., Standard financial accounting of small and medium micro-entities that are effective from 1 January 2018. So far, MSME has recorded a financial statement with a manual report that only calculates the expenditure and income that has been earned in the given period. In the determination of the selling price of MSME, actors do not calculate the overhead costs and labor costs. The selling price determined by the MSME is only determined by the capital and the profit to be obtained. Overhead and labor costs are not calculated into the price calculation of production, but rather a deduction of income to calculate the profit. For the calculation, the amount of profit that has been calculated by MSME does not reflect the actual profit.

The results of the survey conducted by the Indonesian Internet Service Provider Association (APJII) in 2017 showed that 143.26 million Indonesian people are active as Internet users, 58.08\% of them are residents of Java. To facilitate MSME in implementing accounting properly and properly need support tools so that MSME can make financial reports properly and correctly. The tool that can be used is the 5.7.4 version of the Akuntansi UKM app developed by WiinFeel and can be accessed for free on the Google Play Store. Based on the above phenomenon, it is necessary to do research on the application of Akuntansi UKM applications to MSME in Bekasi city to test the influence of accounting recording by using Android application and manual recording, whether it has a significant difference in the calculation of business profit.

Accurate accounting is needed for business actors, including MSME, to know financial information. Accounting records must be in accordance with the transaction and recorded in accordance with the applicable accounting standards (Andrianto, Nuraini, \& Maharani, 2017). The current accounting records conducted by MSME do not necessarily reflect the actual financial information, MSME does not charge overhead and labor costs to products to be sold so that the resulting profit is not a real return. Adequate and reliable accounting records will reflect the real financial situation (Savitri and Saifudin, 2018). Based on the formulation, the hypotheses are as follows: = There is a significant difference in the recording of profit by MSME with the recording of profit in accordance with the accounting standards.

Conducting accounting records using the SME accounting application will be more detailed than manually recording accounting. In performing accounting records on the application, start from creating a journal to automatically generate financial reports. In accounting recording, using the Akuntansi UKM application will be more detailed, and all transactions will be recorded, including overhead and labor costs, so that it will generate financial statements with the actual profit.

Based on research conducted by Ria (2018) proved that MSME, after the use of Android-based financial applications, could obtain information on financial statements that are getting good and 
accurate. In another study conducted by Nainggolan et al. (2019) proved that an Android-based cash management application is capable of delivering efficiency for MSME in performing cash management so as to display more detailed and accurate calculation information. Furthermore, the research was done by Zahro et al. (2019) proved that after using an Android-based application then MSME does not need to do manual recording of the expense and acceptance cycles so that the resulting reports are more computerized and in accordance with the applicable accounting standards. The first objective of the study was to test the difference in profit recording conducted by MSME with the recording in accordance with accounting standards. The second objective is to test the feasibility of Akuntansi UKM application in implementing MSME.

\section{METHOD}

This research is a case study research conducted to examine a particular object. The Data obtained from the research results are analyzed and can only be generalized in related samples. This research uses quantitative descriptive methods that describe or describe the events that occur using numbers. The samples in this study were MSME in Bekasi City as many as 40 MSME. Prior to the research, a pilot test was conducted with the number of respondents as many as 30 respondents. Respondents were given the question of determining the cost of production, selling price, and profit calculation. Each respondent must fill in the matter according to his knowledge and in accordance with the records that are usually done. Once all the questions are filled, the hypothesis testing is done. Hypothesis testing using a paired test sample t-test to see the difference in the average record of profit performed by MSME with the recording that complies with accounting standards. Feasibility test for UKM Accounting Application using PIECES analysis. The PIECES analysis consists of Performance, Information, Economy, Control, Efficiency, and Services analysis. PIECES Analysis Questionnaire was adopted from Dewi et al. (2016) and several points of inquiry were developed and adapted to MSME conditions in Bekasi city.

\section{RESULTS AND DISCUSSION}

Table 1 shows the test results of normality. The Data in this study has been normally distributed so that it can be continued into the next statistical test.

Table 1. Normality Test

\begin{tabular}{ll}
\hline & Unstandardized Residual \\
\hline $\mathrm{N}$ & 40 \\
Test Statistic & 0.182 \\
Asymp. Sig. (2-tailed) & $0.002^{\mathrm{c}}$ \\
\hline Source: SPSS &
\end{tabular}

Table 2 shows the test results paired sample correlation. The results of paired sample correlations showed a sig value of $0.002<0.005$, which means there is a strong and significant correlation between the calculation of profit by MSME with the appropriate calculation of accounting standards.

Table 2. Paired Sample Correlation

\begin{tabular}{llll}
\hline & N & Correlation & Sig. \\
\hline Pair 1 Before After & 40 & 0.483 & 0.002 \\
\hline Source: SPSS & & &
\end{tabular}

Table 3 shows test results paired test samples. The results of the test paired sample test showed a sig (2-tailed) value of 0.002 , which means there is a difference in the apparent average of profit recording by MSME with the recording in accordance with accounting standards. 
Table 3. Paired Sample Test

\begin{tabular}{rrrrrr}
\hline & Mean & t & df & \multicolumn{2}{c}{ Sig. (2-tailed) } \\
\hline Pair 1 Before After & 1734684,075 & 3,349 & & 39 & 0,002 \\
\hline
\end{tabular}

Source: SPSS

The hypothesis on this research is supported, i.e., the recording of profit by the MSME differs significantly from the recording in accordance with accounting standards. Accounting for MSME is not compliant with accounting standards. The initial recording mistake occurred is the listing price of the production. Out of the 40 respondents, only one respondent was in the recording of the production cost. The other respondents in calculating the cost of production included all the costs and expenses that had been incurred over the period, resulting in the amount of production base price too large. In addition, respondents are still not able to identify which transactions are classified into raw materials and overhead costs. It is also one of the reasons for the recording of the underlying product price is not in fact. Confusion in the price recording of the production tree will result in confusion in the sale price. The selling price will be too high if the percentage of profit has been determined first, or the percentage of profit will be too low if the selling price has been determined first. The error on the sale price will impact the revenue received and will affect the logging of the profit. So the profit recorded will not show the actual profit.

The results of PIECES analysis for the use of Akuntansi UKM application are as follows: In the performance indicator, there are four statements that measure the extent of the performance of Akuntansi UKM application, following statements in performance indicators:

Table 4. Performance Indicator Statement

\begin{tabular}{cl}
\hline Number & \multicolumn{1}{c}{ Statement } \\
\hline 1. & Menu and navigation options make it easy to use the program \\
2. & Menu and navigation provided can be run easily and interactively \\
3. & Response slowness occurs when an application is used \\
4. & Easy command cancellation instructions while required \\
\hline
\end{tabular}

Source: Research questionnaire

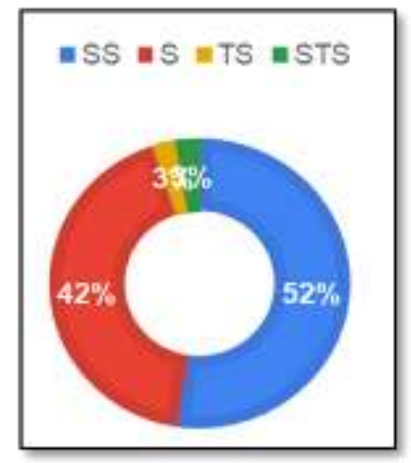

Figure 1. Statement 1 Performance

In Figure 1, It is stated that $52 \%$ of respondents strongly agree and $42 \%$ agree that the menus and navigation available are easy to use. Other respondents were as much as $3 \%$ disagree with, and the other $3 \%$ strongly disagreed the menu and navigation available are easy to use. In other words, as much as $94 \%$ feel the menus and navigation available are easy to use. 


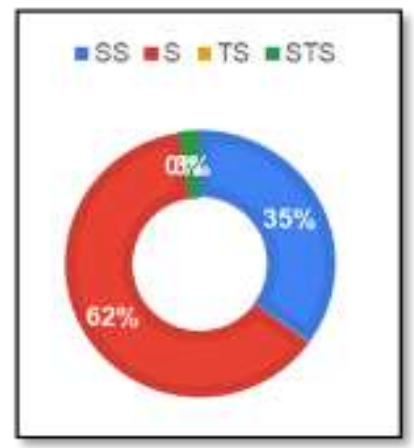

Figure 2. Statement 2 Performance

In Figure 2, It is stated that $62 \%$ of respondents strongly agree and $35 \%$ agree that the menus and navigation provided can be run easily and interactively. Other respondents, as much as $3 \%$, strongly disagree with the menu, and the provided navigation can be run easily and interactively. In other words, as much as $97 \%$ feel the menu and navigation can be run easily and interactively.

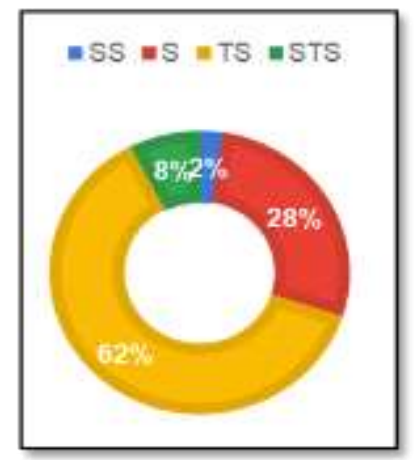

\section{Figure 3. Statement 3 Performance}

In Figure 3, It is stated that $62 \%$ of respondents disagree, and $8 \%$ strongly disagree that there is a response slowness when the application is used. More than $28 \%$ of respondents agreed, and $2 \%$ were very much agreed on response lags when applications were used. In other words, as much as $70 \%$ felt there was no response lag when the application was used.

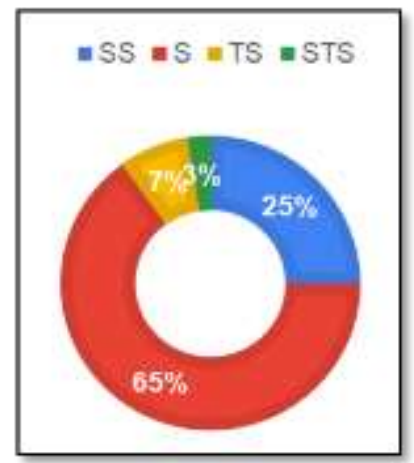

\section{Figure 4. Statement 4 Performance}

In Figure 4, It is stated that $65 \%$ of respondents agreed, and $25 \%$ strongly agree that there are available command cancellation instructions easily while required. The other respondents as much as $7 \%$ disagree, and $3 \%$ of respondents very disagree that are available command cancellation 
instructions easily while required. In other words, as much as $90 \%$ felt the command cancellation instructions were easy to understand and run.

In the information indicator, there are four statements that measure the extent to which information in the SME accounting application can facilitate the work. Following statement in the information indicator:

Table 5. Information Indicator Statement

\begin{tabular}{cl}
\hline Number & \\
\hline 1. & Available menus are easy to understand \\
2. & In the application, there are information/guidance needed \\
3. & Available information needed when inputting new transactions \\
4. & The resulting output is easy to understand
\end{tabular}

Source: Research questionnaire

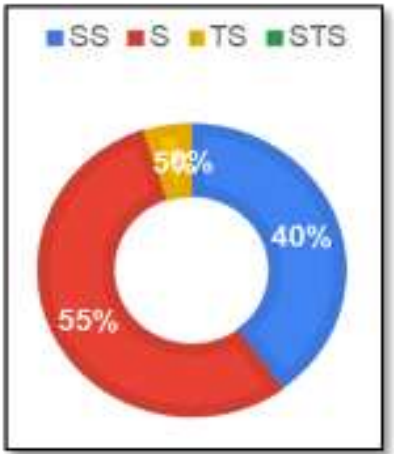

Figure 5. Statement 1 Information

In Figure 5, It is stated that $55 \%$ of respondents agreed and $40 \%$ strongly agree that the available menus are easy to understand. Another $5 \%$ of respondents do not agree the available menus are easy to understand. In other words, as much as $95 \%$ felt the menus available in the SME accounting application are easy to understand.

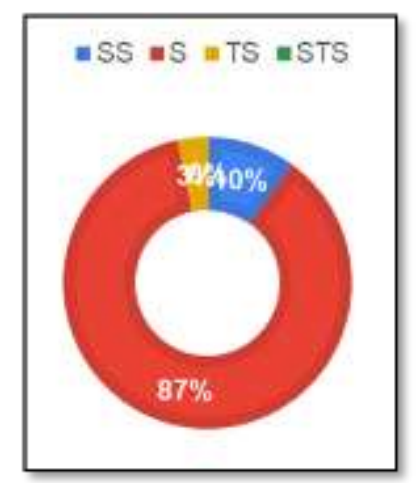

Figure 6. Statement 2 Information

In Figure 6, It is stated that $87 \%$ of respondents agreed, and $10 \%$ strongly agree that in the application, there is information/guidance needed. Other respondents, 3\%, disagree in the application there is information guidance needed. In other words, as much as $97 \%$ feel the information and guidance available in the application according to their needs. 


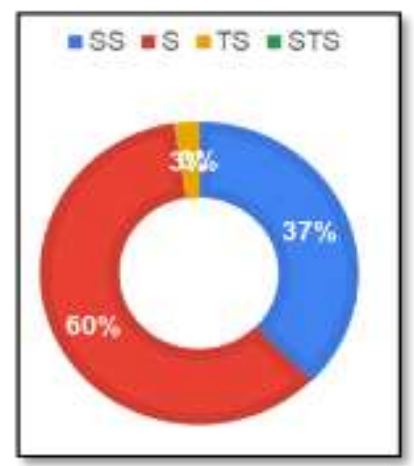

Figure 7. Statement 3 Information

In Figure 7, it is stated that $60 \%$ of respondents agreed, and $37 \%$ strongly agree that there is the information needed when inputting new transactions. Other respondents, as much as $3 \%$, disagree is available the information needed when inputting new transactions. In other words, as much as $97 \%$ of respondents feel when they will input new transactions available information needed.

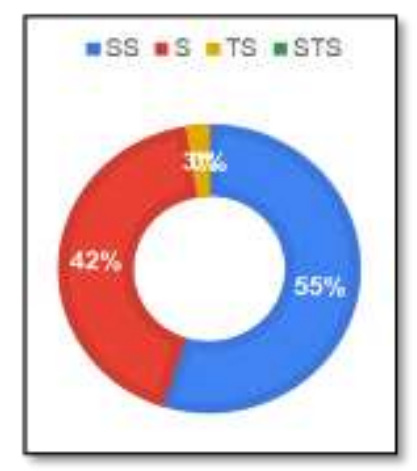

Figure 8. Statement 4 Information

In Figure 8, It is stated that $42 \%$ of respondents agreed, and $55 \%$ strongly agree that the resulting output is easy to understand. The other $3 \%$ of respondents disagree that the resulting output is easy to understand. In other words, as much as $97 \%$ of respondents felt the resulting output is easy to understand. The resulting output is a financial statement in the form of the income statement and financial position report.

In the economics indicator, there are four statements that measure the economics level of use of MSME accounting application, following the statement in the economics indicator:

\section{Table 6. Economics Indicator Statement}

\begin{tabular}{cl}
\hline Number & \\
\hline 1. & Akuntansi UKM application is easy to get for free \\
2. & Akuntansi UKM application does not consume a lot of quotas \\
3. & Using the Akuntansi UKM application can save operational costs \\
4. & Benefits gained after using the Akuntansi UKM application are greater than the \\
& Internet quota issued.
\end{tabular}

Source: Research questionnaire 


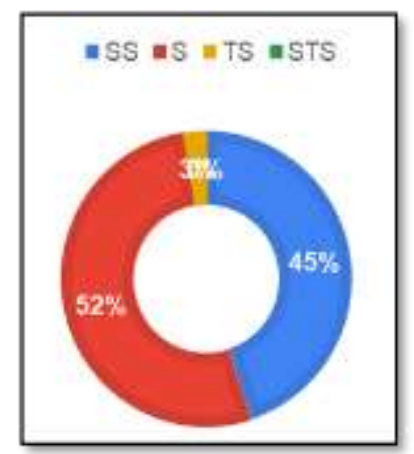

Figure 9. Statement 1 Economics

In Figure 9, It is stated that $52 \%$ of respondents agreed, and $45 \%$ strongly agree that the Akuntansi UKM application is easily obtained for free. Another $3 \%$ of respondents did not agree that the Akuntansi UKM application is easy to obtain for free. In other words, $97 \%$ of respondents felt the Akuntansi UKM application is easy to obtain for free.

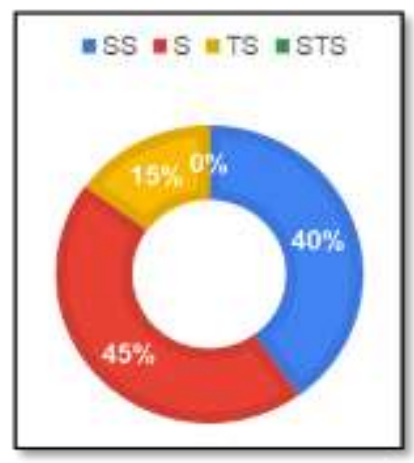

Figure 10. Statement 2 Economics

In Figure 10, it is stated that $45 \%$ of respondents agreed, and $40 \%$ strongly agree that the Akuntansi UKM application does not spend much quota. Of the other respondents, $15 \%$ did not agree that the Akuntansi UKM application did not spend much quota. In other words, $85 \%$ of respondents feel the use of the Akuntansi UKM application does not require a lot of quotas because the use of this application can be used in offline circumstances.

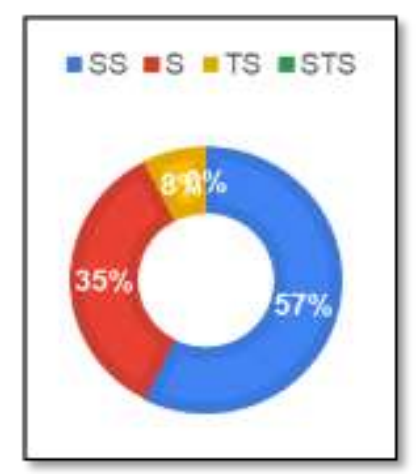

Figure 11. Statement 3 Economics

In Figure 11, It is stated that $35 \%$ of respondents agreed, and $57 \%$ strongly agree that using the Akuntansi UKM application can save on operational costs. Other respondents, 8\%, do not agree that using the Akuntansi UKM application can save operational costs. In other words, $92 \%$ of 
respondents felt the use of the Akuntansi UKM application saves operational costs. The costs that are usually used to make current financial statements can be minimized because the use of this Akuntansi UKM application does not require any fees.

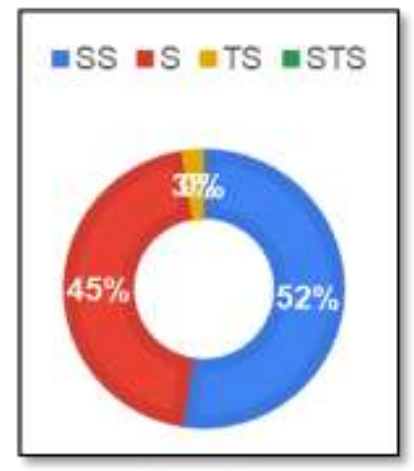

Figure 12. Statement 4 Economics

In Figure 12, it is stated that $45 \%$ of respondents agreed, and $52 \%$ strongly agree that the benefits gained after using the Akuntansi UKM application are greater than the Internet quota issued. Other respondents, $3 \%$, disagree that the benefits gained after using the Akuntansi UKM application are greater than the Internet quota issued. In other words, $97 \%$ of respondents feel the benefits gained after using the Akuntansi UKM application is greater than the cost of the internet to be incurred. The use of the Akuntansi UKM application does not require an Internet quota so that the benefits that are charged by the user will be greater than the cost incurred.

In the control indicator, there are four statements that measure the level of user control of Akuntansi UKM application, following statements in the control indicator:

\section{Table 7. Control Indicator Statement}

\begin{tabular}{cl}
\hline Number & \multicolumn{1}{c}{ Statement } \\
\hline 1. & There is a security system in the Akuntansi UKM application that can be trusted \\
\hline 2. & There is data backup that allows users to search for past data \\
\hline 3. & $\begin{array}{l}\text { By using the Akuntansi UKM application, The business finances can be } \\
\text { controlled well }\end{array}$ \\
\hline 4. & Akuntansi UKM application can be controlled according to the needs.
\end{tabular}

Source: Research questionnaire

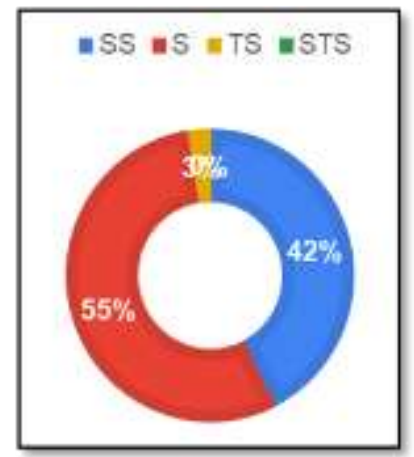

Figure 13. Statement 1 Control

In Figure 13 , It is stated that $55 \%$ of respondents agreed, and $42 \%$ strongly agree that there is a security system in the Akuntansi UKM application that can be trusted. Another 3\% of respondents do not agree that there is a security system in the Akuntansi UKM application that can be trusted. 
In other words, $97 \%$ of respondents felt that the security system in the Akuntansi UKM application could be trusted. The in-app security system uses a PIN that has already been plotted at the beginning of application usage. The security system that has recorded financial data can not be abused by others.

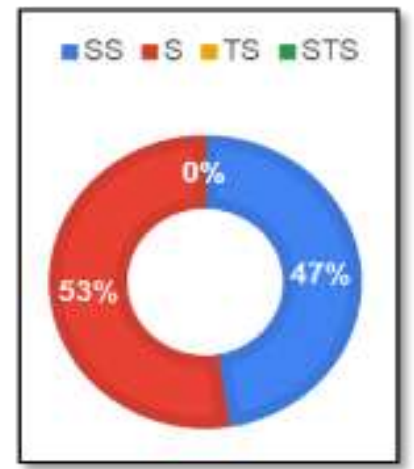

Figure 14. Statement 2 Control

Figure 14 stated that $53 \%$ of respondents agreed, and $47 \%$ strongly agree that there is a data backup that makes it easy for users to search for past data. In other words, all respondents feel that the data backup system can make it easier for users to search for past data. With this data backup system, users will be able to keep data securely even if changing devices because all input data will be back up and can be restored on a new device. Figure 14 stated that $53 \%$ of respondents agreed, and $47 \%$ strongly agree that there is a data backup that makes it easy for users to search for past data. In other words, all respondents feel that the data backup system can make it easier for users to search for past data. With this data backup system, users will be able to keep data securely even if changing devices because all input data will be back up and can be restored on a new device.

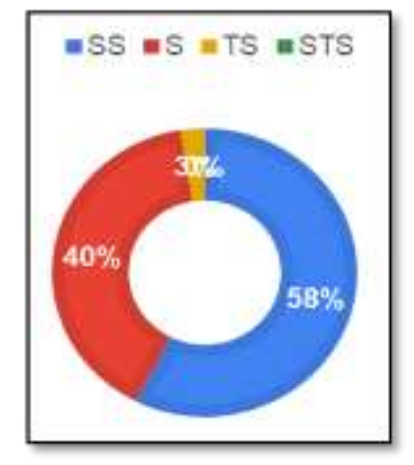

Figure 15. Statement 3 Control

Figure 15 stated that $40 \%$ of respondents agreed, and $58 \%$ strongly agree that by using the Akuntansi UKM application, The business finances can be well controlled. Other respondents, as much as 3\%, disagree with the use of Akuntansi UKM application Business finance can be well controlled. In other words, as much as $98 \%$ of respondents felt their business could be well controlled if using the SME accounting application. In the Akuntansi UKM application, financial records can be controlled by activating the reminder, and with the correct record, then the user will know the balance per account so as to facilitate the user to know their credit and control the finances. 


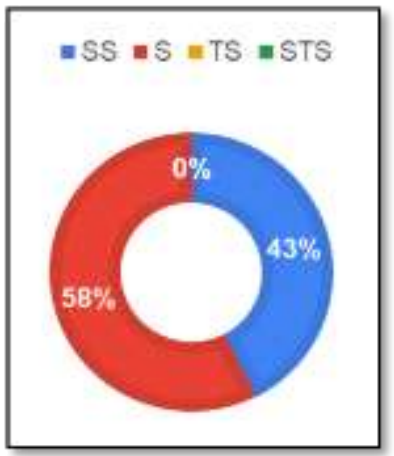

Figure 16. Statement 4 Control

In Figure 16, It is stated that $58 \%$ of respondents agreed, and $43 \%$ strongly agree that the Akuntansi UKM application can be controlled according to the needs. In other words, all respondents feel the Akuntansi UKM application can be adapted to the needs of each respondent. Akuntansi UKM application can be used by MSME that sells merchandise, processed goods, and services so that all MSME can use the application according to their needs.

In the efficiency indicator, there are four statements that measure the efficiency level of use of Akuntansi UKM application, following statements in the efficiency indicators:

\section{Table 8. Efficiency Indicator Statement}

\begin{tabular}{cl}
\hline Number & \multicolumn{1}{c}{ Statement } \\
\hline 1. & Akuntansi UKM application speeds up job completion \\
2. & The resulting financial statements are trustworthy and accurate \\
3. & $\begin{array}{l}\text { Using the Akuntansi UKM application can facilitate the completion of the } \\
\text { financial report }\end{array}$ \\
4. & $\begin{array}{l}\text { Using the Akuntansi UKM application can facilitate the completion of the } \\
\text { generation of an annual tax return. }\end{array}$
\end{tabular}

Source: Research questionnaire

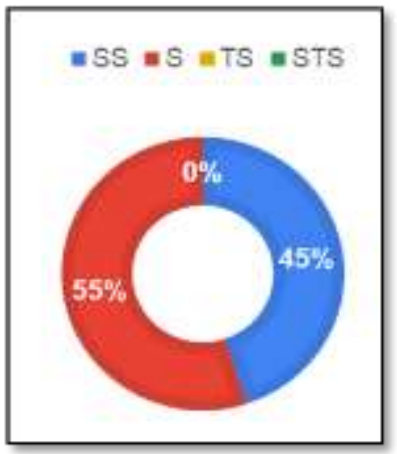

Figure 17. Statement 1 Efficiency

In Figure 17, It is stated that $55 \%$ of respondents agreed, and $45 \%$ strongly agree that the Akuntansi UKM application accelerated the completion of the work. In other words, all respondents feel when using the SME accounting application job to compile financial statements can be faster because, in the system, the application users only need to enter transactions, and financial statements will be automatically made. 


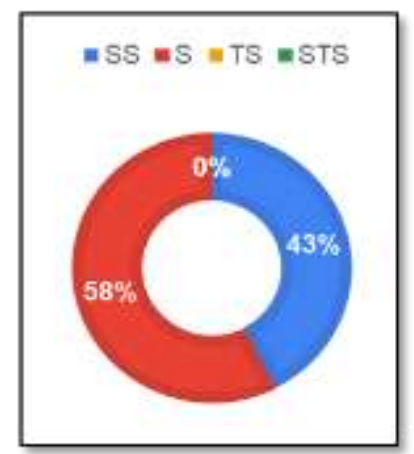

Figure 18. Statement 2 Efficiency

In Figure 18 , it is stated that $58 \%$ of respondents agreed, and $43 \%$ strongly agree that the resulting financial statements are trustworthy and accurate. In other words, all respondents feel the financial statements that are produced can be trusted so that it can be used for decision making.

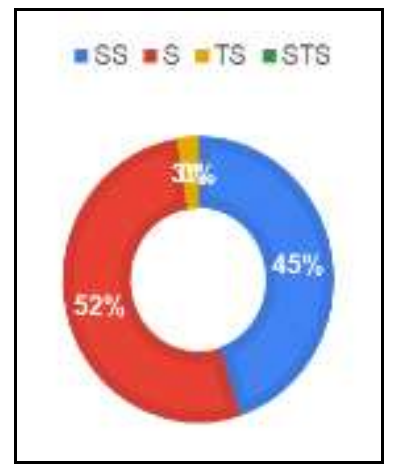

\section{Figure 19. Statement 3 Efficiency}

In Figure 19, It is stated that $52 \%$ of respondents agreed, and $45 \%$ strongly agree that using the Akuntansi UKM application can facilitate the completion of financial statement generation. At the same time, as many as $3 \%$ of other respondents do not agree that the use of the Akuntansi UKM application can easily resolve financial statements. In other words, 97\% of respondents felt that using the app could facilitate the preparation of financial statements.

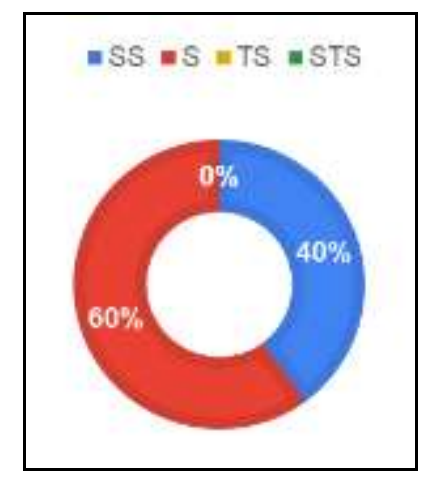

Figure 20. Statement 4 Efficiency

Figure 20 stated that $60 \%$ of respondents agreed, and $40 \%$ strongly agree that using the Akuntansi UKM application can facilitate the completion of the generation of the annual tax return. In other words, all respondents felt that the generation of an annual tax return could be simplified when using the application. 
In the service indicator, there are four statements that measure the level of service usage of Akuntansi UKM application, following statement in Service indicator:

Table 9. Efficiency Indicator Statement

\begin{tabular}{cl}
\hline Number & \multicolumn{1}{c}{ Statement } \\
\hline 1. & $\begin{array}{l}\text { There is a help menu that can make it easier to use when users have difficulty } \\
\text { operating } \\
\text { 2. }\end{array}$ \\
Manual/Application Usage guide can be easily obtained so as to facilitate users in \\
the operation \\
A reminder menu is available that makes it easy for users to set schedules \\
(example: annual tax return, receivables billing to customers, etc.) \\
Application to automatically complete the account entry system according to \\
transactions, making it easier to create journals
\end{tabular}

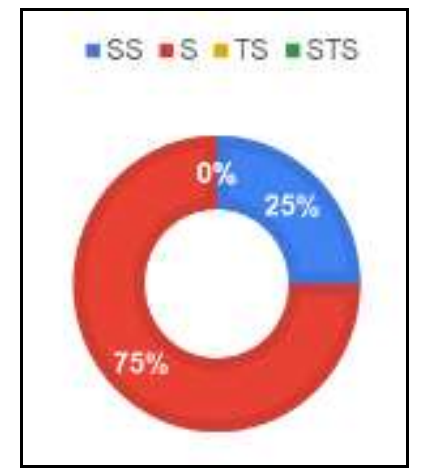

Figure 21. Statement 1 Service

In Figure 21, It was stated that $75 \%$ of respondents agreed, and $25 \%$ strongly agreed that there is a help menu that can make it easier to use when users have difficulty operating. In other words, all respondents feel when they have difficulty asking for help from the operator via the email listed in the application. In addition, in the Application menu, there are also helpful in the form of a module book that contains the application procedures and can be downloaded by all users.

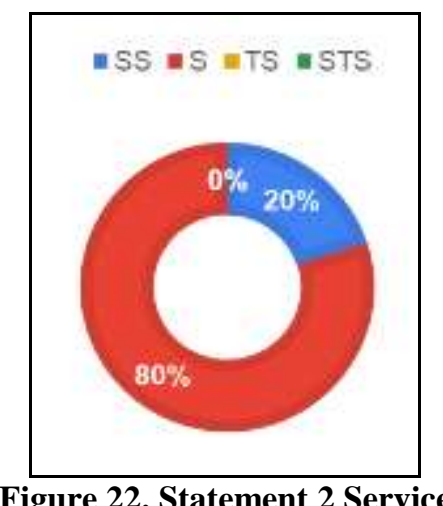

Figure 22. Statement 2 Service

In figure 22 , It is stated that $80 \%$ of respondents agreed, and $20 \%$ strongly agree that the manual/Application usage guide can be easily obtained so as to facilitate the user in operation. In other words, all respondents find it easy to operate the application because there are guidelines in application usage ranging from transaction input to the printing of financial statements. 


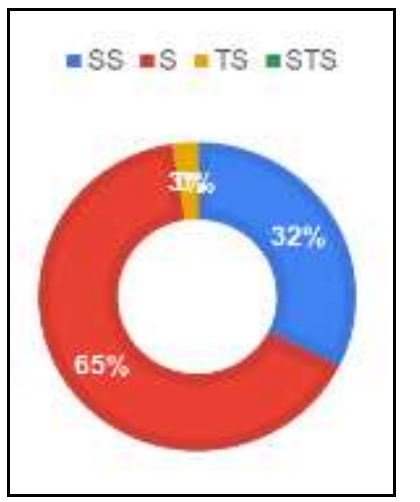

Figure 23. Statement 3 Service

In Figure 23, It is stated that $65 \%$ of respondents agreed and $32 \%$ strongly agree that a reminder menu is available that makes it easy for users to set schedules (e.g., annual tax return, billing receivables to customers, etc.). At the same time, the other $3 \%$ of respondents don't agree that the reminder menu can make it easier for users to set schedules. In other words, as much as $97 \%$ feel the reminder menu can help the user to set up the schedule so that the schedule of annual tax return, receivables Billing, and other schedules can be carried out in accordance with the specified time.

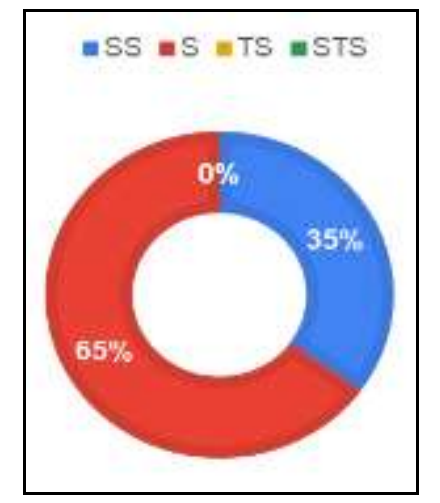

Figure 24. Statement 4 Service

In figure 24 , It is stated that $65 \%$ of respondents agreed, and $35 \%$ strongly agree that the application automatically completes the account entry system according to transactions, making it easier to create journals. In other words, all respondents feel that the journal preparation can be made easy by using the application because the user only enters the transactions, and journals that will be created automatically will be composed.

\section{CONCLUSION}

Accurate accounting recording and in accordance with accounting standards are indispensable for businessmen. One of them is MSME. The MSME in determining the selling price does not charge the overhead and labor costs to the products to be sold. From the process, the specified selling price is not in accordance with the expected because the accounting recording is not in accordance with accounting standards. With this problem, it will need to be further examined whether there is a difference in profit recording while on MSME records with the recording in accordance with accounting standards. The test results stated that there was a significant difference between the profit recorded by the MSME with the profit that has been recorded in accordance with accounting standards. With the significant differences, there is a need to be a supply or training to MSME in 
determining the cost of production, selling price, and profit calculation so that the profit recorded by the MSME reflects the real profit.

The easy recording of accounting, there is an Akuntansi UKM application that can help MSME to compile financial statements. The Akuntansi UKM application has been tested for its behavior using the PIECES method, and the result is that the Akuntansi UKM application is in accordance with all indicators in PIECES so that the application is feasible for MSME use. Limitations in the application are not able to calculate the cost of production and determine the selling price automatically so that in the use of such applications, users need to understand the calculation of production costs and the determination of the sale price manually.

\section{ACKNOWLEDGEMENT}

Kementrian Riset dan Teknologi/ Badam Riset dan Inovasi Nasional Throught Lembaga Layanan Pendidikan Tinggi Wilayah IV. According to the research contract, number: 158/ SP2H/ LTMONO/ LL4/ 2020.

\section{REFERENCE}

Andrianto, A., Nuraini, F., \& Maharani, R. (2017). Pencatatan Akuntansi pada Usaha Peternakan Ayam Petelur ( Studi Kasus Usaha Peternakan Ayam Petelur di Kecamatan Sugio Lamongan ). Majalah Ekonomi, 22(1), 1-7.

Asosiasi Penyelenggara Jasa Internet Indonesia. (2017). Infografis Penetrasi dan Perilaku Pengguna Internet Indonesia. APJII.

Badan Pusat Statistik Kota Bekasi. (2019). Produk Domestik Regional Bruto. "https://bekasikota.bps.go.id/statictable/2017/08/10/75/pdrb-kota-bekasi-atas-dasar-hargakonstan-2010-menurut-pengeluaran-juta-rupiah-2014-2018.html" https://bekasikota.bps.go.id/statictable/2017/08/10/75/pdrb-kota-bekasi-atas-dasarharga-konstan-2010-menurut-pengeluaran-juta-rupiah-2014-2018.html. Download on 14th August 2019

$\begin{array}{llllll}\text { Cendana } & \text { News. } & \text { (2018). Jumlah } & \text { UKM } & \text { di }\end{array}$ Meningkat.https://www.cendananews.com/2018/12/jumlah-ukm-di-kota-bekasimeningkat.html" https://www.cendananews.com/2018/12/jumlah-ukm-di-kota-bekasimeningkat.html . Diunduh pada 14 Agustus 2019.

Dewi, R. S., Marchada, R. R., \& Rifai, A. (2016). Analisa PIECES Penerapan Digital MonitoringInformasi Penyewaan Ruko Pasar 8 pada PT Alam Sutera Realty, Tbk. Seminar Nasional Teknologi Informasi dan Komunikasi (pp. 644-648). Yogyakarta: SENTIKA.

Kurniawati, E. P., Nugroho, P. I., \& Arifin, C. (2012). Penerapan Akuntansi pada Usaha Mikro, Kecil, dan Menengah (UMKM). JMK, 10(2), 1-10.

Nainggolan, E. R. et al. (2019). Aplikasi Manajemen Kas Berbasi Android Untuk Membantu Pelaku Usaha Kecil dan Menengah: Jurnal Pendidikan Informatika dan Sains, 8 (1)

Pinasti, M. (2007). Pengaruh penyelenggaraan dan penggunaan informasi akuntansi terhadap persepsi pengusaha kecil atas informasi akuntansi: suatu riset eksperimen : Jurnal Riset Akuntansi Indonesia, 10 (3)

Ria, A. (2018). Analisis Penerapan Aplikasi Keuangan Berbasis Android pada Laporan Keuangan UMKM Mekarsari, Depok: Sosio e-kons, 10 (3)

Savitri, R.V. dan Saifudin. (2018). Pencatatan Akuntansi pada Usaha Mikro Kecil dan Menengah: Jurnal Manajemen Bisnis dan Inovasi, 5 (2)

Zahro, N. A. Indrianasari, N. T. Yatminiwati, M. (2019). Analisis Penerapan Aplikasi Akuntansi Berbasis Android SI Apik Untuk Memenuhi Kebutuhan Sistem Informasi Akuntansi di 
E-ISSN : 2549-5992, P-ISSN : 2088-0944 Available online at: http://ejournal.stiewidyagamalumajang.ac.id/index.php/wiga

Usaha Kecil (Studi Kasus pada Alfin Souvenir Lumajang). Posiding Progress Conference. 